Denisa BUD

Faculty of Letters, “Babeș-Bolyai” University

Cluj-Napoca, Romania

denisa.bud17@yahoo.ro

\title{
THE ROMANIAN NOVELS OF THE 'OBSESSIVE DECADE’ AS \\ SUBVERSIVE LITERATURE. A MACROANALYSIS (1971-1979)
}

Recommended Citation: Bud, Denisa. "The Romanian Novels of the 'Obsessive Decade' as Subversive Literature. A Macroanalysis (1971-1979).” Metacritic Journal for Comparative Studies and Theory 5.1 (2019): https://doi.org/10.24193/mjcst.2019.7.11

\begin{abstract}
This paper attempts to investigate the prevalence of the novels of the 'obsessive decade' in the '70s, using the means of the quantitative studies and macroanalysis, as they are theorised by Franco Moretti and Matthew L. Jockers. We will focus on how the subversive nature of the novels of the 'obsessive decade' can be detected through quantitative analysis of textual structures (thematic, lexis). In the political context of the '70s, due to the imposing of certain restrictions (we are referring to the July Thesis of 1971), the situation of Romanian literature changed. One of the decrees of the Communist Party, proposed in 1964 due to the installation of Nicolae Ceaușescu's totalitarian regime, was to develop a critique of the dogmatism of the '50s. In the '70s, the novels of the 'obsessive decade' were viewed as subversive by censorship and by literary criticism. Therefore, the main focus of my paper is to re-discuss the subversive formula of the novels of the 'obsessive decade' in the '70s, from a different and innovative point of view, within a quantitative approach.
\end{abstract}

Keywords: 'obsessive decade', subversive literature, novel, censorship, macroanalysis.

Romanian post-war literature remains of interest in contemporary literary-historical studies because of its political commitment, but also through the debates woven around literature written during the communist regime. The novel of the 'obsessive decade' finds itself among the most controversial cultural subjects under the 
Ceauşescu communist regime because of its complexity, under the aspect of its political implications, as well as under the aspect of the themes it addresses. The concept of the 'obsessive decade' was introduced in Romanian literary history by the post-war writer Marin Preda, but literary criticism uses the term with another meaning1. After the introduction of communism in Romania, the post-war communist period is segmented into three distinct periods: the socialist-realism period of the 1950s, under the reign of Gheorghiu-Dej, a period in which political repression is the strongest, the second period, that of relative liberalization, 1965-1970, which makes its debut as Nicolae Ceaușescu takes the lead as General Secretary of the Romanian Communist Party, and the last one, that of "neodogmatism” (Malița 54), spanning 1971 to 1989. The second period of the Ceaușescu regime, 1971-1989, follows after a massive cultural and literary change after the publication of the July Theses in 1971 and is generally considered a period of redogmatisation and of excessive nationalism. What the July Theses aimed to achieve is carefully emphasized by Sanda Cordoș:

A resuscitation of socialist realism is attempted by Nicolae Ceaușescu in the speeches he holds in the summer of 1971, better known as the July Theses. His visits to China, made before he held said speeches, did not offer the general secretary of the Romanian Communist Party a model of cultural revolution, but rather a pretext to return to 1950 s socialist realism and to the theses formulated by A. A. Jdanov, which he mainly copies when talking about the fact that "Art must serve a single purpose: the communist-socialist education”2 (Cordoș 19).

Thus, in the Party's vision, literature must first of all promote political principles and always have an image of the new, communist man in mind: "The writers were expected to «more firmly promote the Party's aesthetic principles, to fight for a realist culture, that would help the cause of socialist development, the shaping of the

${ }^{1}$ For a more complex history of the concept, Alex Goldiș's article is a necessary reading (Goldiş, "Morfologie" 494-502).

2 "O resuscitare a ideologiei realismului socialist o încearcă Nicolae Ceaușescu în discursurile susținute în vara anului 1971, cunoscute sub numele de Tezele din iulie. Consider că vizita în China, făcută înainte de pronunțarea acestor discursuri, nu i-a oferit secretarului general al P.C.R. un model de revoluție culurală, ci un pretext pentru reîntoarcerea la realismul socialist al anilor '50, la tezele rapoartelor lui A. A. Jdanov pe care, în mare măsură, le reia, vorbind despre faptul că: «Arta trebuie să servească unui singur scop: educației socialiste comuniste»” (My translation). 
consciousness of the new man"” (Malița 54). On the one hand, some literary critics regard this as the reemergence of dogmatic literary phenomena, whereas others note the emergence of a form of literature which is aesthetically relevant despite the Party's interdictions. For example, when talking about the period between 1971 and 1989, Ion Simuț claims that "[the] general atmosphere becomes more and more gloomy and tensed from 1971 to 1989. Editorial plans are revised, reduced and modified through the addition of books of propaganda"4 (Simuț 260). Expressing a similar opinion, Eugen Negrici is talking about censorship's increased "severity" (Negrici 57). Nonetheless, the situation of the Romanian novel proves to be quite different.

A research based on the quantitative approach has the means to clarify the situation of the Romanian novel during communism. We are proposing another way of investigating its evolution by analysing the prose fiction of the 'obsessive decade'. Furthermore, an overview of the Romanian novel spanning from 1971 to 1979 is needed, and macroanalysis can reveal something that was often ignored or left behind in literary history and criticism, namely what Franco Moretti calls "the great unread" (Moretti, "Slaughterhouse" 225-7). Placing national literatures in a world system (Wallerstein), in this case, through the quantitative approach, is equally important, both for its marketability - so the national literatures will be more accessible to foreign public - as well as for placing it in a broader literary context. While the novel of the 'obsessive decade' used to occupy an insignificant position in critical studies prior to 1990 , it is only starting from 2000 that in-depth analyses begin to discuss this typology of Romanian prose. A quantitative research puts forward another way of peering into this type of novel, but, as Matthew L. Jockers also claims, quantitative research cannot completely replace traditional modes of analysis, but is ultimately just another method of addressing literature, one that lays emphasis on elements that are usually left behind (Jockers 15). Thus, quantitative methods aim to configure literature more openly, without excluding the specificity of one literary space or another, and "a macroanalytic approach helps us not only to see and understand the operations of a larger «literary economy», but, by means of scale,

3 "Li se pretindea scriitorilor să «promoveze, cu mai multă fermitate, principiile estetice ale partidului, să lupte pentru o cultură realistă, care să slujească cauza construcției socialiste, formarea conştiinței omului nou»” (My translation).

4 "Atmosfera generală devine din ce în ce mai sumbră și mai apăsătoare din 1971-1989. Planurile editoriale sunt revizuite, reduse, modificate prin adaosuri de cărți de propagandă" (My translation). 
to better see and understand the degree to which literature and the individual authors who manufacture that literature respond to or react against literary and cultural trends" (Jockers 52). Without demanding the complete elimination of close reading, Jockers emphasises the relevance of big data precisely because it can make visible the information that gets lost in close reading and the seemingly insignificant aspects of traditional literary research (Jockers 16). Also, earlier than Jockers, Franco Moretti accentuates in his articles the idea of big data through distant reading (Moretti, "Conjectures" 54-68) and the great unread (Moretti, "Slaughterhouse" 207-27). Despite the fact that, more often than not, macroanalyses are prone to raise more questions than to give definitive answers (Jockers 103), they offer new starting points for research and enable broad literary overviews. Moretti pleads for the revival of literary studies because "graphs, maps, and trees place the literary field literally in front of our eyes - and show us how little we still know about it" (Moretti, Graphs 2). And that is exactly what happened in the case of the political novel and, more specifically, in the case of the prose labelled under the 'obsessive decade'; the generalisation of this type of novel took place because of a series of symptomatic texts from the given time frame. But, as the same scholar further claims, "it's not even a matter of time, but of method: a field this large cannot be understood by stitching together separate bits of knowledge about individual cases: it's a collective system, that should be grasped as such, as a whole - and the graphs that follow are one way to begin doing this" (Moretti, Graphs 4).

That is why the present study aims to follow the novel of the 'obsessive decade' between 1971 and 1979 through the lens of quantitative analysis and simultaneously question whether or not the most debated novels of the given period possess a subversive character. The first section includes a quantitative overview of the Romanian novel from the 70s, to get a clearer insight into this decade, largely regarded within Romanian literary history as a prolific stage in the development of the 'obsessive decade' novel. Furthermore, this section will analyse the political novel in relationship with all the other novelistic genres, precisely because the novelistic typology which makes the object of this study falls into the category of political prose. The second segment hosts a case-study, where, by employing the same method of quantitative analysis, we will examine several of the symptomatic novels of the 'obsessive decade' from the 1970s. More exactly, the analysis will delve deeper into textual microstructures which have come under censorship's scrutiny and we will try 
to assess whether or not they support claims of subversion. A notable and relevant definition of subversive prose that we will further employ in this study is given by Alex Goldiş: "By «subversive prose» I do not mean a strong ideological opposition to the totalitarian system (with few exceptions, direct opposition was never possible in any of the cultures under Soviet influence), but an attempt to render more flexible the rules of production of literary works: in other words, an endeavor to open up the literary system" (Goldiş, "Interferences" 87).

Considering the fact that the last period in Romanian communism is a period of strong re-dogmatisation, the situation of the Romanian novel during the '70s must be analysed as objectively as possible. Research centred on close-reading often produced limited samples which it then extrapolated to include the whole period in question, and that is why an analysis based on the principles of quantitative research offers a different way of relating to the Romanian novel of this decade. As Jockers himself claims, a bird's-eye view perspective can point the researcher towards totally different directions. The material employed in the first section of my study is the Chronological Dictionary of the Romanian Novel from its Origins to 1989 (Dicționarul cronologic al romanului românesc de la origini până la 1989 or DCRR), which was published by the Romanian Academy and indexes all prose texts published between 1844 and 1989 in Romania, while simultaneously annexing a bibliographical list. Furthermore, the dictionary lists both the text's novelistic category, as well as offering a short description for each novel. The research is based on the novels listed in the dictionary, but not on the prose fragments published in the decade's literary periodicals. The study represents an analysis that employs the method of distant reading (Moretti, "Conjectures" 56-8); its first segment follows the general structures of the Romanian novel and its categories, and in the case of the political novel, we are especially interested in one of its subcategories, namely the prose of the 'obsessive decade'. The first part of our research consisted in indexing the novels following criteria like the genre of the novels and the subgenre (from the descriptions) in the case of the 'obsessive decade' novel.

In regard to the categories that the Dictionary proposes, they partially respect a unanimously accepted convention, which we also accept within this paper, whilst being aware that we risk simplifying, something that all scholars of World Literature are aware of in their research. The graphs aim to offer an overview of the Romanian novel in a totalitarian regime and to illustrate the complexity of novelistic genres 
against the claims of a unique literature, as well as to give a clear view over the novel of the 'obsessive decade'.

The literature produced in the last stage of Romanian communism, between 1971 and 1989, was often the object of heated debates in Romanian criticism due to historical and political - thus extra-literary - events. On the one hand, literary critics take into account the re-emergence of dogmatic tendencies within literature, whereas other critics lay emphasis on the existence of an aesthetically relevant literature. Anton Cosma - the author of an anthology which follows the evolution of the Romanian novel between 1945-1985 - considers that this "is a stage where the obsessive search for the truth of recent history, the one that had been the object of a strict taboo up until 1965, diminishes, while the most serious truths seem to have already been said, and writers are on an obstinate search for something else: the novel itself, literature instead of the political testimony and of the indictment literature" 5 (Cosma 64). The reason behind a stronger political control is represented by the July Theses of 1971, which give way both to a more rigorous control over literary production, as well as to the emergence of the personality cult in the public sphere. Yet, in the case of prose, things seem a little different. To this regard, Mircea Martin, one of the Romanian literary critics of the so-called '6os generation, makes the following observation:

The dis-ideologising tendency within culture and especially within literature continues despite the numerous propagandistic campaigns and the July Theses with their consequences. The agent of this gradual dis-ideologisation and of the symbolic delegitimisation not only of communism, but also of nationalism, the catalyst or even the dissolving acid, was aestheticism itself ${ }^{6}$ (Martin 19).

Despite the oppressive regime, the macroanalysis of the Romanian novel points to a whole different conclusion at a macroanalytical level, which does nothing but reinforce the claims of several critics. Emmanuelle Dauriac talks about a "cultural

5 "Este o etapă în care obsesia adevărului despre istoria recentă, cea tabuizată până în 1965 , pălește, adevărurile cele mai grave părând, pesemne, a fi fost, de-acum, spuse, și scriitorii caută tot mai obstinat altceva: romanul însuși, literatura în locul mărturiei și al rechizitoriului” (My translation).

6 "Dezideologizarea în interiorul culturii și, mai ales, al literaturii continuă, în ciuda, încă o dată, a atâtor campanii propagandistice și a 'tezelor din iulie' 1971 cu consecințele lor. Agentul acestei dezideologizări treptate, al deligitimării simbolice, nu numai a comunismului, dar și a naționalismului, catalizatorul sau chiar acidul disolutiv a fost esteticul însuşi” (My translation). 
effervescence" (Dauriac 48-55) representative for the 1970s. Novelistic production between 1971 and 1979 reaches 954 titles, more than during the period of socialist realism - which doesn't come as a surprise, actually - but also more than during the period of relative liberalism, preponderantly interpreted as a blooming period for literature.

\section{Statistical distribution of the novel. 1971-1979}

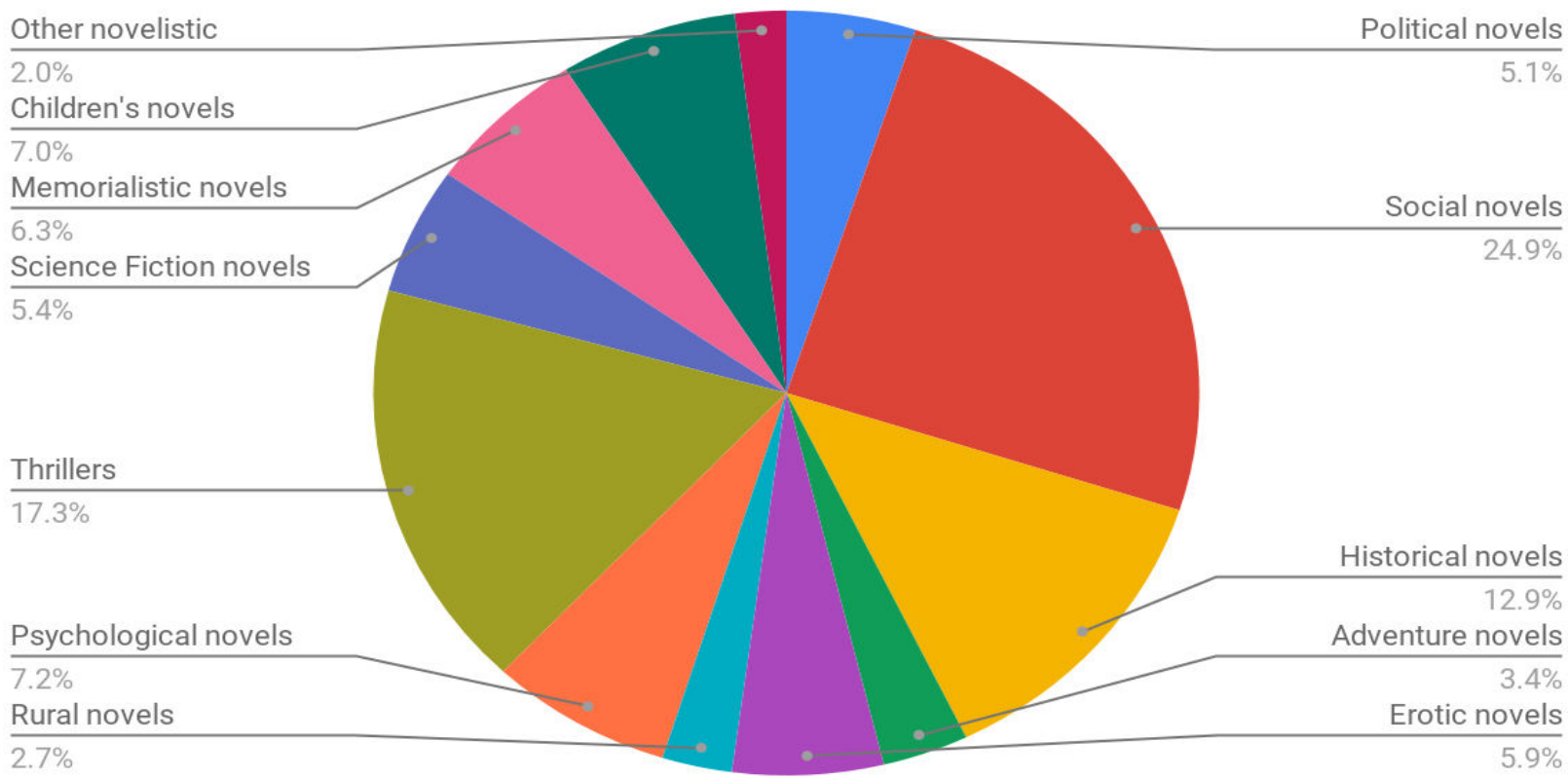

The pie chart above (Fig. 1) represents an overview of the Romanian novel of the ' 70 s based on the categories listed in the DCRR. Concerning the nature of categories indexed in the DCRR7, we find Daiana Gârdan's studies quite relevant for the situation of the quantitative research in Romania and, also, the hardships of the existent dictionaries which can produce errors (Gârdan, "Evoluția” 5-10; Gârdan, "Unread" 109-24). The chart demonstrates the diversity of the novelistic genres during a decade of strong political control within literary production. The most important category for the aim of this study is the political novel, of which the prose labelled as belonging to the 'obsessive decade' is a significant part. If the Party's new directives, together with the July Theses, attempted to impose a literature that laid emphasis on the leader's personality cult, while simultaneously being under censorship's control, our graph points to another conclusion. The political novel is

${ }^{7}$ Mihnea Bâlici's article must be seen, for he exposes the limits of the quantitative research in Romania and the objections to using the categories of the DCRR (Bâlici 11-18). 
found but in a modest percentage and only a small part of it is represented by the category of the ideologised novel, namely the "realist novel (based on verisimilitude and representation) [...] prone to demonstrate the truth of a certain political doctrine"8 (Suleiman 14). The social novel registers the highest value and reveals the fact that prose is seeking to portray the relationship between the individual and society. Also, it follows the mechanisms through which society has effects over human individuality and, also, it has a psychological side which reflects the conflicts of the human in a world of restrictions. On the other hand, the political novel represents a mere $5.1 \%$ of the novelistic production of the 1970 , which sufficiently demonstrates that neo-dogmatisation (Malița 54) was not particularly effective in this sense, especially because not all political novels adopted an ideological stance. To this regard, the observation of Viorel Nistor, the author of a synthesis of the Romanian political novel, holds true: "In the period of literature's last dogmatisation, the last of its kind during communism and during this revival of the censorship apparatus, the explicitly political novel, consecrated as such, is partially avoided in favour of evasive literature"9 (Nistor 9). In late communism, as stated by the descriptions of novels from DCRR, the social novel aims at situations like the evolution of a character in society, living in a city, the existence of intellectuals or social environment and the political novel accentuates the theme of power and its mechanisms. The difference between those two categories is to be found on the thematic level. In both cases, as the descriptions from DCRR show, there are some texts which have an ideological dimension. What can be observed from indexing the categories put together in the Dictionary is that several of the novelistic categories tend to conform to the principles imposed by censorship, as is the case with the rural novel (which most often portrays a village life subordinated to the communist worldview), the children and adolescent novel (which aims towards educating young minds in the spirit of communism) or the crime fiction novel (which rather tends towards portraying communist spies) ${ }^{10}$. Thus, as Figure 1 also reveals, the novel of

8 "Je definis comme roman à thése un roman «realiste» (fondé sur une esthétique de vraisemblable et de la représentation) [...] tendant à démontrer la vérité d'une doctrine politique” (My translation).

9 "În perioada ultimei dogmatizări a literaturii, ultima a comunismului, de recrudescență a cenzurii, romanul politic explicit, consacrat în această formulă, este în parte ocolit, lăsând loc unei literaturi de tip evazionist” (My translation).

10 In DCRR, for these categories, there are descriptions like "novel for children, feel of adventure, fantasy, cautionary references"; "crime fiction novel. Are investigated theft cases of art objects from museums"; "rural novel with the theme of younger intellectuals assigned to the village"; 
the 1970s succeeds in not falling victim to political control and to become a tool in the Party's hands despite it becoming the object of censorship's attention. Although the critical research addresses but a couple of texts, the verdicts of literary criticism are firm in their claim that the political novel not only exists, but that it represents a dominant genre, and in regard to the highly debated novels of the 'obsessive decade', the critics' claims of a spike in their number is questionable.

The novel of 'the obsessive decade' fell under the scrutiny of critical debates starting in the 1980s, as the literary inquiry The Romanian Novel - today was published in one of the 1983 numbers of the Critical Notebooks (Caiete Critice). There is evidently a difference between the critical opinions put forward on the matter before 1989 and those launched after 1990. Ioan Buduca talks about the political novel as a novelistic genre limited to "what has been named the 'Obsessive Decade' "11 (Buduca 148), Eugen Simion considers that prose took on a political stance starting in the 1970s, and that at the level of novelistic morphology, it is either confessional or documentary, the latter choosing the 'obsessive decade' as its main reference point (Simion, "Romanul" 70); Eugen Negrici insists upon "a revised image of the 1950s" in "the so-called 'political prose" "12 (Negrici 295), while Anton Cosma emphasises the fact that "the horrors, the abuses of the 1950s, the individual's relationship with power and with revolution, his role as their instrument or as their victim are recurrent themes of the political novel of the $8^{\text {th }}$ decade" 13 (Cosma 105-6). Choosing another approach, Nicolae Manolescu makes a clear distinction between political novels and novels with a political theme and claims that the novels of the 'obsessive decade' are to be integrated into the latter category, since they are, in fact, "historical and social novels"14 (Manolescu, Arca 251). Marcel Corniș-Pop suggests the use of another concept to designate this novelistic type, namely the redeeming novel, and that it is a form of "narrative of indictment"15 (Corniş-Pop 3). Studies published after 2000 that mention the novel of the 'obsessive decade' offer a

„a novel for children, inspired by the activity of pioneers at a karting circle"; "crime fiction novel with psychological accents, fighting for moral recovery of criminals” (DCRR 2004).

${ }_{11}$ "[...] teritoriul a ceea ce s-a numit 'obsedantul deceniu" (My translation).

12 “[...] imagini revizuite a anilor '50" în "așa-zisa 'proză politică”" (My translation).

13 "Erorile, abuzurile din anii '5o, raportul insului cu puterea și cu revoluția, situația lui de instrument sau victimă a acestora, sînt teme predilecte ale romanului politic în deceniul opt" (My translation).

14 "[...] romane istorice și sociale" (My translation).

15 "[...] un roman de tip anchetă" (My translation). 
different point of view. Mihai Iovănel presents a different image of such prose yielding subversive undertones:

A great deal of the successful literary formulas employed during communism 'the political novel' of the 1970s, for example, discussed the political abuses of the 1950 or the difficulties inherent to the industrialisation and modernisation processes and so on - have made their debut, at least partially, as acts of individual courage, wherein the author risked his livelihood or expected some sort of a trench-war with censorship and with all the other institutions responsible for political control over publishing houses ${ }^{16}$ (Iovănel 28).

In his book on the institution of censorship under communism, Liviu Malița considers that placing literary figures in the period of socialist realism is barely a textual strategy, and that the prose of the 'obsessive decade' focuses on the "critique of the present” (Malița 189). On the other hand, Alex Goldiș draws attention to the concept of the 'obsessive decade' itself: "The abusive or simplifying interpretations start from the concept's origins themselves. It is attributed to Marin Preda, but confronting the text where it supposedly appeared for the first times obscures its meaning rather than clarifying it"17 (Goldiș, "Morfologie" 494). Whereas the articles published before 1989 are preponderantly expositive, with their authors defining the novel of the 'obsessive decade' while often lacking solid arguments, the studies published after 2000 question this novel's whole formula, simultaneously reassessing the different ways in which it can be either ideologically instrumented by the Party in order to launch a critique of the Gheorghiu-Dej regime or regarded as subversive, whereas the critique they express is interpreted as a critique of the political present in which they were published. The present study addresses precisely this aspect, namely the extent to which the novels of the 'obsessive decade' published between 1971 and 1979 possess a subversive character, seen through the lens of World Literature studies.

16 "O bună parte din formulele de succes ale literaturii scrise în comunism - 'romanul politic' al anilor '70, de pildă, punea în discuție abuzurile politice din anii '50 sau dificultățile inerente ale procesului de industrializare și modernizare etc. - au început, măcar în parte, ca fenomene de curaj individual, în care autorul își risca situația sau cel puțin își asuma lungul meci de uzură cu cenzura și cu toate celelelalte instituții de control a tipăriturilor” (My translation).

17 "Interpretările abuzive sau simplificatoare pornesc, din păcate, chiar de la stabilirea originii conceptului. El este atribuit lui Marin Preda, însă o confruntare cu textul care se presupune că l-a lansat mai degrabă îi obscurizează sensurile decât să le limpezească.” (My translation). 
An important aspect to be taken into consideration is the number of novels categorised under the 'obsessive decade' during the 1970s. Thus, according to the aforementioned Dictionary, only $26.5 \%$ of the novels are listed as such. The critical claims according to which the $8^{\text {th }}$ decade was one in which the novel of the 'obsessive decade' proliferated are thus disproved by this factual information. This generalisation was possible due to the prominence of several of the period's significant novels (belonging to authors such as Augustin Buzura, Constantin Țoiu or Marin Preda), who, both through their literary impact and through the critical reception they received, gave the impression that this type of novel constitutes a richer category. Moreover, literature in the 1970 s "becomes less and less political"18 (Iovănel 61), a fact confirmed by Figure 1 as well.

In a Romanian context, there is little research that systematizes subversion in the literary sphere and, more often than not, it fails to sufficiently problematise the relationship between the political and the literary that the subversive novel requires during the communist period, and the texts' subversive character is regarded as a subjective and even interpretable matter. Furthermore, through their "allusive" nature and through the issues they address - that inevitably imply adopting a clear position in regard to censorship - the subversive novels catch censorship's attention. Several of the critics that have approached the subject notice the formation of an authentic literature precisely through the subversive use of themes that were considered taboo in the period. Consequently, the subversive novel is hereby defined as literature that takes on a polemical stance in regard to the communist system, a stance most visible at the level of novelistic formulas and thematic choices. Thus, the novels of the obsessive decade construct only partial forms of subversion inasmuch as they condone the Ceaușescu regime by being critical towards the horrors of the 1950s, but this "follows the same distancing strategy - but reduces it to a minimum, if you may: the object of the fictionalisations of this category is the historical 'obsessive decade', yet the subversive stakes - where they exist - rather regards the present"19 (Goldiș, "Morfologie” 496-7).

Thus, despite being one of the most powerful institutions of the totalitarian state, censorship functions, in the case of the subversive novel, as a 'productive

18 “[...] devine tot mai puțin politică" (My translation).

19 “[...] mizează pe aceeași strategie a distanțării - doar că o reduce la minim, dacă se poate spune astfel: ecranul ficţiunilor din această categorie îl reprezintă 'obsedantul deceniu' în sine, însă miza subversivă - acolo unde ea există - e îndreptată asupra prezentului” (My translation). 
phenomenon', and the observation made by Clara Tuite is revealing in this sense: "I mean productive not in the sense that censorship is benign, but in the sense that it facilitates textual and performative agency as well as the productive reception and performance of the literary text" (Tuite 34), because, in spite of strict political rules, the post-war Romanian literary system welcomes the emergence of several significant novels. This is why we consider that a systematic analysis that aims to quantify lexical structures that would have made the object of the censorship's scrutiny and distrust is an efficient method of questioning the subversive character attributed to the novels of the obsessive decade by literary critics.

The second part of my study examines the subversive character of several of these novels that have been listed in the Dictionary as novels belonging to the 'obsessive decade' and which have made the object of critical attention both as they were first published, in the period's periodicals, as well as in more specialised and lengthy studies. The selection covers three novels, namely The Great Loner (Marele Singuratic, 1972), by Marin Preda, one of the significant writers of the Romanian Post-war literature; The faces of Silence (Fețele tăcerii, 1974), by Augustin Buzura, a writer of the so-called '6os generation, and The Gallery with Wild Vines (Galeria cu viță sălbatică, 1976), by Constantin Țoiu, one of the writers of Romanian Post-war literature. The terms searched for in the systematic analysis were selected based on the literary themes which were most often in censorship's attention, a part of which were discussed by Liviu Malița (Malița 2016) and included both elements considered specific for the prose of the 'obsessive decade' such as 'collectivisation' and the figure of the 'Party activist' (Malița 191), as well as terms belonging to religion, the motherland, the personal Ego, reality or truth.

The aim of such a type of research is to factually show whether or not the subversive character of the main novels belonging to the 'obsessive decade' can be confirmed at the level of lexical structures associated to themes distrusted by censorship. For this research, we have made use of the first editions of the novels in question. We find it necessary to mention that we are well aware of hypothetical errors that could find their way into our study due to the lack of more advanced digital instruments and taking into account the backwardness of quantitative research in Romania. Before we get to the actual presentation of the graphs, we first have to mention the approach of this second part of the research: the three mentioned novels were scanned and we performed a distant reading which consisted 
in the counting of lexical structures, established on the basis of the themes which were on censorship's attention, identified by Liviu Malița. The counting of lexical structures was made manually, there wasn't any program or algorithm employed. The thematic topics used and the terms we have chosen to include in each one are: reality, the ego (uncertainty, anxiety, pessimism, fear), love (love, affection, emotion), history, religion (church, scepticism, mysticism, metaphysical, God), the Rural (collectivisation, the peasant, peasantry), power, the motherland (The Party, communism, socialism, militia, comrade, activist, illegality, leader, enemy), truth, death. Another section is dedicated to deviant terms: abuse, hunger, cold. The distribution of the former category of terms illustrates the relationship between literature and censorship's control when the authors, bypassing censorship, attempt to represent reality in its authentic light. The following pie chart (Fig.2) follows the factual representation of the themes which are to be found in Marin Preda's 1972 novel, The Great Loner.

\section{Figure 2. The Great Loner. Marele singuratic, Marin Preda}

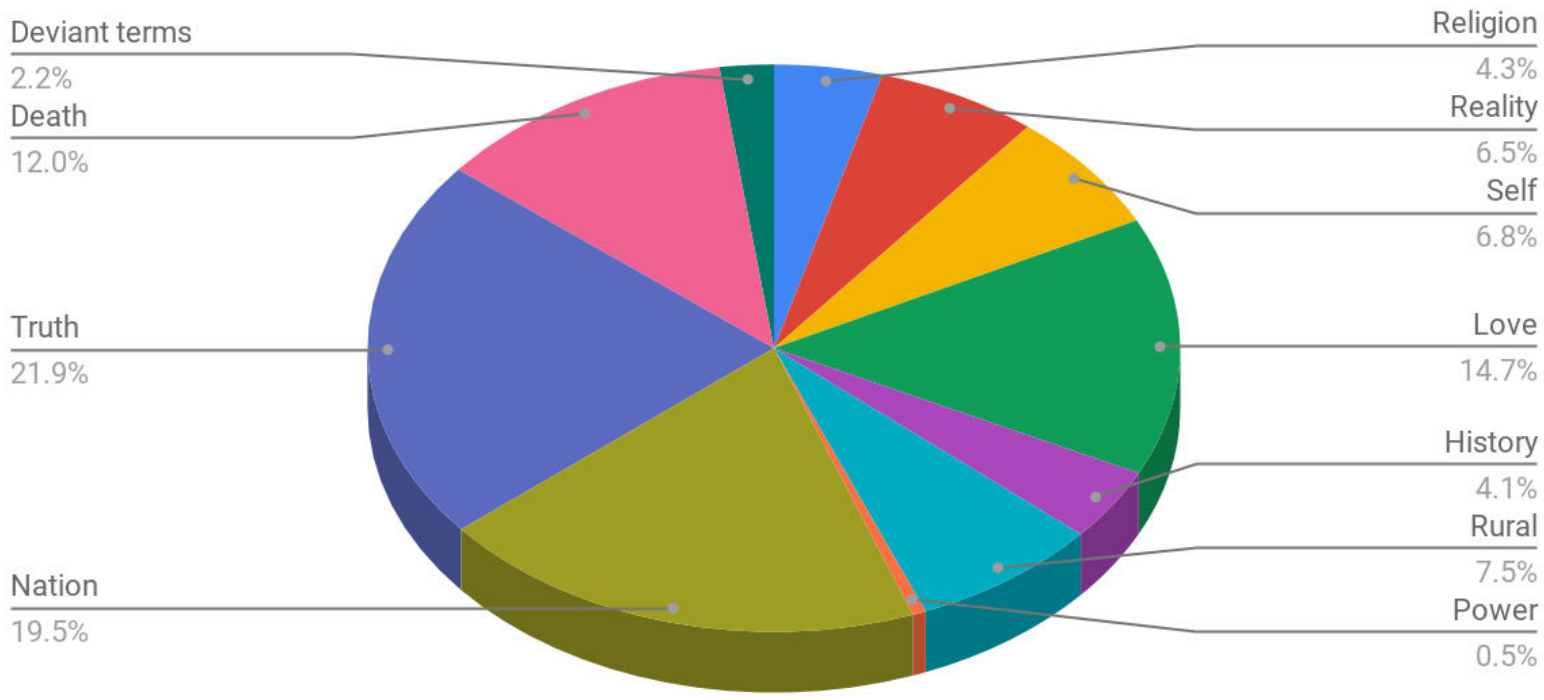

As Figure 2 shows, the themes with the highest degree of representation in the novel are those related to truth and the motherland, a fact that confirms the critical opinions that claimed that Preda's text emphasises the relationship between the individual and society or, as Eugen Simion puts it, "the relationship between the 
individual's personality and historical determinism"2o (Simion, "Procedeu" 4). That is to say that in The Great Loner, truth is not objective and unchangeable, but rather it is filtered through individual consciousness, which automatically points toward subversion, inasmuch as the communist system cultivates a single type of truth, the truth formulated by the Party itself. Furthermore, two other topics of great interest for the institution of censorship are death and love, which, as it can be observed in the chart, are relatively well represented when compared to the others. Thus, emotion, affection (subordinated to the topic of love) supports the claim about the novel's subjectivity. Moreover, death contributes to the formation of a pessimistic worldview, in stark contrast to the positive image of "the new man" (Malița 253). The reality and the Ego point toward the same conclusion: the terms associated with the 'real' convey the idea of an individual reality and the terms associated with the Ego are 'uncertainty' and 'fear', thus enforcing a pessimistic view. As for religion, the following aspects are to be noted: the term is frequently encountered in expressions such as "a new religion" (Preda 1972), as the protagonist, Niculae, gives voice to his ambitions of creating new societal values; additionally, the elements associated with this topic ('church', 'God') are often mentioned sarcastically. Far from being the novel of an era, that of the obsessive decade, Preda's novel is far more complex, because it engages the relationship between the individual and history, but the emphasis falls rather on the issues of humanity and on the negative aspects of communist reality, something that does nothing but confirm its subversive character.

The third pie chart (Fig. 3) illustrates the topics identified in Augustin Buzura's 1974 novel, The Faces of Silence, a novel that provoked quite a debate within the ranks of literary criticism. Through a novel such as The Faces of Silence, the whole concept of the novel of the obsessive decade took shape in critical studies, something which the quantitative analysis boldly disproves, as mentioned before.

20 “[...] raportul dintre personalitatea individului și determinismul istoriei” (My translation). 
Figure 3. The Faces of Silence. Fețele tăcerii, Augustin Buzura

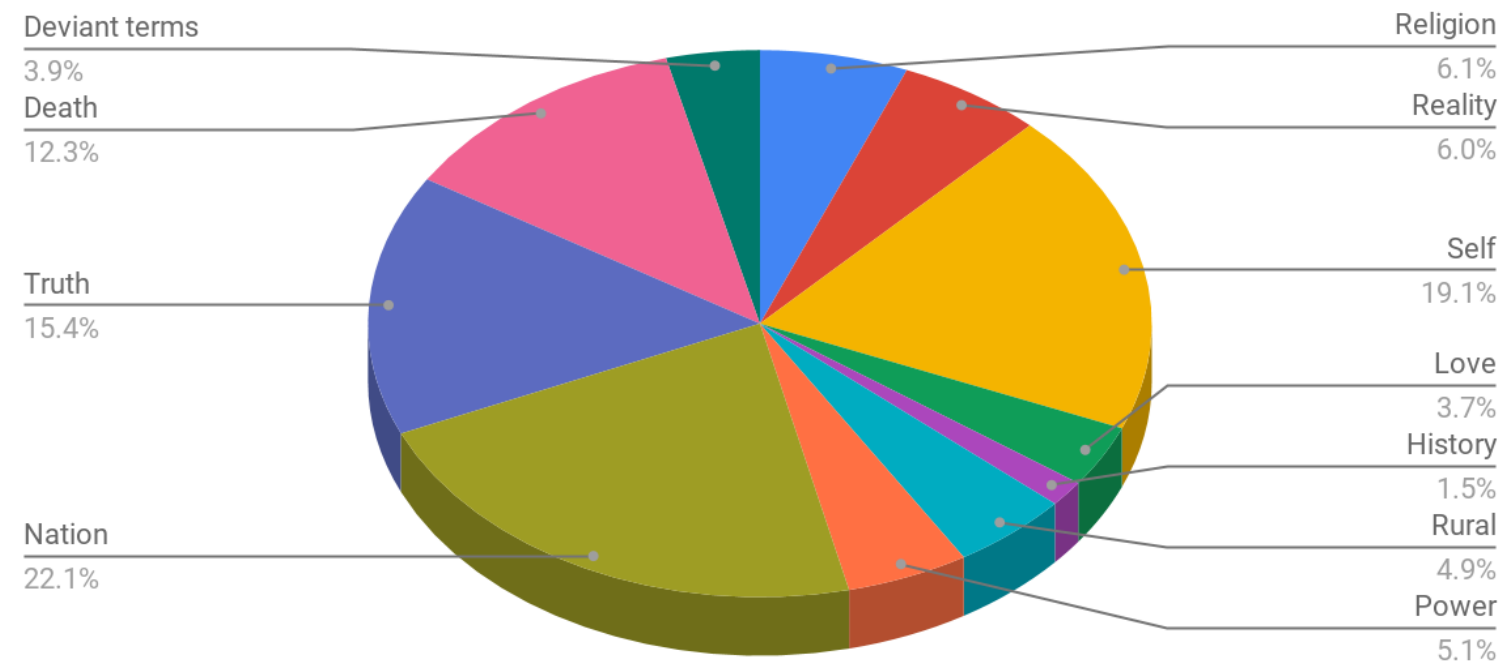

Buzura's text revolves around social issues (represented through the topic of the motherland) and on human psychology (evoked through the topic of the Ego, love or power). The terms that fall under the incidence of the topic of motherland are used either in evidently sarcastic contexts - for example, when using the term 'comrade', the typical form of address in communist Romania - or polemically, such as explicitly naming 'communism' within the novel. The origin of communism, as well as its current directions, are two of the significant topics in the novel, which sometimes even evokes a negative image of the communist system: "They couldn't live without Westerners, neither did they like socialism, and since the West didn't give a damn about them, they though to themselves that it's better to go to hell than live in communism"21 (Buzura 493). As for the topic of the Ego, the highest values are met by 'fear' and 'uncertainty', elements that help describe communist reality. Thus, these two prove their validity both for the 1950s, as well as for the Ceaușescu period in Romanian communism and subsequently prove their subversive nature. Through criticising the 'obsessive decade', the post-1965 period is equally criticised. What Buzura also signals and promotes is the idea of truth and of its expression: "Truth

21 "Nu putuseră trăi fără occidentali, socialismul nu le pica bine, iar cum pe Occident îl durea în spate de ei, au găsit de cuviință că decât în comunism, mai bine în iad” (My translation). 
can and must be said"22 (Buzura 365), alluding to a critique of the communist system and of its falsities. Often enough, two of the analysed deviant terms, 'fear' and 'hunger', are grouped together precisely to emphasise the communist reality. As for the topic of death, which is to be found quite frequently, as Fig. 3 also shows, it is either regarded with sarcasm - "a festive death, like during one of your meetings" 23 (Buzura 44) - or associated with terror and psychical distress. This expression designating 'psychical death' possesses an allusive character and can be regarded as a metaphor for the communist suppression of the individual self. While the novel is critically interpreted as telling the story of the collectivisation of a village during the 1950s (Manolescu, "Fețele" 9), the quantitative analysis demonstrates without a doubt that the rural is not predominant at all, but that the most important are the truth and the representation of reality.

The last of the three novels chosen for the analysis is Constantin Ţoiu's The Gallery with Wild Vines, featured in the following pie chart (Fig. 4).

\section{Figure 4. The Gallery with Wild Vines. Galeria cu viță sălbatică, Constantin Țoiu}

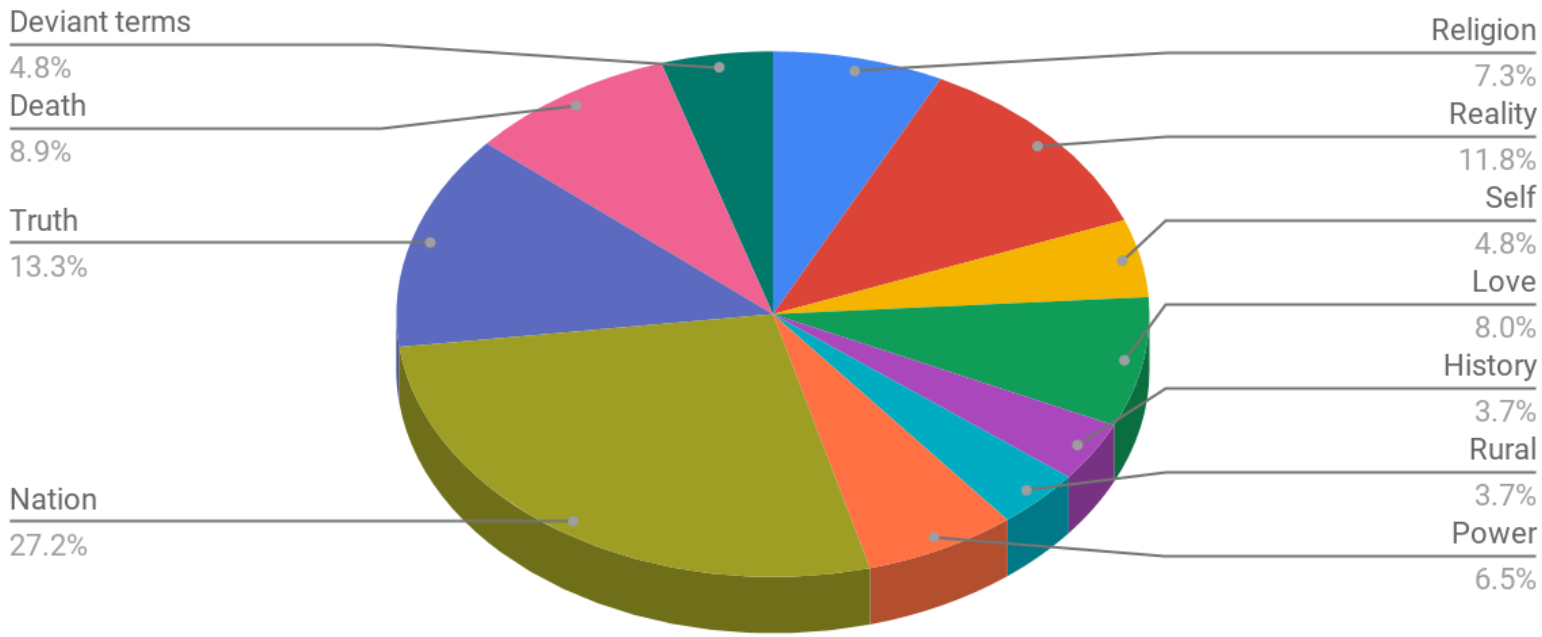

The main topic identified in the novel, and the one with the highest degree of representation, is the motherland. Thus, here as well, communism represents a

22 "Adevărul poate și trebuie spus" (My translation).

23 "[...] o moarte festivă, ca o ședință de-a dumitale" (My translation). 
pivotal reference point and often even becomes the source of debate. Far from letting it remain just a theoretical idea, Țoiu expresses an equivalence between communism and human individuality: "Communism was a universal idea that used to have hundreds of millions of disinherited, famished and illiterate people on its side, without them even knowing it, and whose only awareness regarded their own oppression"24 (Țoiu 119-20). Besides this relationship between the political and the individual sphere, the critical stance against the regime is evident. One can also notice a focus on certain topics such as truth and reality. The question of reality is regarded objectively, which means that, in the case of the present novel, reality is not seen through a subjective lens, but it is rather understood at the level of realist representation. Furthermore, the topic of death occupies a significant percentage of the novel's progression, considering also the fact that death was one of censorship's most distrusted themes because of the pessimism it conveys. Thus, even if it theoretically belongs to the 1950s, the issues it raises also address the present time, and a privileged point of debate is represented by the relationship between "individuality and history in the sense of the latter being dependent of the former" 25 (Holban 4).

The purpose of these graphs was to factually demonstrate the preponderance of certain themes or, on the contrary, their absence from these novels. Such an analysis offers another way of delving into the literary themes that censorship was most attentive to. The three novels also have a common ground. In the case of The Faces of Silence and The Gallery with Wild Vines, while addressing the topic of motherland, both novels insist on the problematic relationship between the individual and the political sphere, wherein the term that comes under scrutiny is precisely that of communism. Furthermore, in all three novels, power and reality are closely linked to subjectivity. The first topic, power, is portrayed as a human characteristic rather than as one referring to the political environment. As for the deviant terms, which are to be found in high percentages in Buzura's and Țoiu's novels, the two most common terms are 'cold' and 'hunger', designating two of the aspects of communist reality. Another common element is the obsession of truth that

24 "Comunismul era o idee universală care avea de partea lui, chiar dacă nu întru totul conștienți, sute și sute de milioane de dezmoșteniți, de înfometați și de analfabeți a căror singură știință era oprimarea, cunoscută pe propria lor piele” (My translation).

25 “[...] individualitate și istorie în sensul dependenței celui de-al doilea termen al relației de primul" (My translation). 
lays emphasis on the troubled relationship between the individual and society, between human subjectivity and political reality. In the case of religion, while Preda exercised a form of sarcasm in regard to it, Buzura and Țoiu conserve the sacred in its original sense by often constructing dialogues between their characters revolving around the 'metaphysical realm'. Even though it is not significantly represented in any of these novels, the topic of death is still present and reflects a negative worldview. While the Rural should be highly represented according to researchers taking into consideration that the novels belong to the 'obsessive decade', so they should address collectivisation and rural society - the quantitative analysis strongly disproves this fact. It is only in Preda's novel that this topic reaches $7.5 \%$, whereas in the other two novels it doesn't surpass $5 \%$. This alone automatically points to the fact that, far from being novels with an explicit thesis (that of criticising the political 1950s), they are actually novels possessing a prospective thesis, in the sense that they refer to the historical present of the Ceaussescu regime, a fact that automatically grants them a subversive character. More than this, subversion also is to be seen in the presence of topics such as the Ego, the truth or death. In an unusual occurrence, censorship becomes an element in the creative process, according to Lossef (Lossef 11), and this becomes evident in the thematic complexity of the three novels in question. Also, unlike The Great Loner, where the truth is viewed through a subjective filter, in The Faces of Silence, the truth is in correlation with the social and the operation's mechanisms of the reality of the 'obsessive decade', which are valued in the case of the Ceauşist society. In this case, observation made by Alex Goldiş is relevant:

In Romanian culture, Augustin Buzura, Nicolae Breban and Alexandru Ivasiuc took advantage of the denunciation of Stalinism and deconstructed it in the name of a more unprejudiced communism, represented by the Ceaușescu regime. It is not difficult to observe that under the pretense of exposing the barbarity of the Stalinist decade, these prose writers took aim at the Communist ideology as a whole (Goldiș, "Interferences" 92).

With Marin Preda and Augustin Buzura, the theme of reality represents only 6,5\%, respectively 6\%, while in Țoiu's novel, it registers 11,8\%, which accentuates Constantin Țoiu's preoccupation not only with the 'obsessive decade', but also with 
the reality of communism, considering that in his novel communism represents a source of debate.

In conclusion, the novel of the 'obsessive decade' still remains a subject of debate within this line of research, and a quantitative analysis greatly contributes to the clarification of certain critical positions that have been taken throughout the years by several scholars. The present article sought to analyse the Romanian novel of the 1970 and demonstrated that the political novel is actually a minor category of the given period, despite the regime's oppressive power, and that the political novel is not entirely covered by the novel of the 'obsessive decade', which represents a mere $26.5 \%$ of the total political prose of that time. Ultimately, the quantitative analysis goes against the critical opinions according to which the $8^{\text {th }}$ decade was a prolific period for the novel of the 'obsessive decade'. These opinions were the result of a generalisation caused by the prominence and success of the novels published during this period. The second segment of this study sought to analyse the degree of subversion found in three of the period's most representative novels - authored by Marin Preda, Augustin Buzura and Constantin Ţoiu - by indexing a series of lexical structured associated to themes that have traditionally found themselves in censors' attention. As I have demonstrated, the identification of themes such as truth, death, the Ego and religion demonstrates that the novels in question are not merely the reflection of an era, but that they pursue much more complex issues such as the relationship between history and the individual, which suffices in confirming their subversive character.

\section{References:}

---. Dicționarul cronologic al romanului românesc. București: Editura Academiei Române, 2004 (The Chronological Dictionary of the Romanian Novel from its origins to 1989). Editura Academiei Române, 2004.

Bâlici, Mihnea. "Studii cantitative recente în spațiul românesc. Între analiza insituţională şi problema traducerilor" ("Recent Quantitative Studies in Romania between Institutional Analysis and The Topic of Translation”). Transilvania 2/2019: 11-18.

Buduca, Ioan. "Romanul politic. Aspirație și realitate" ("Political Novel. Aspiration and Reality"). Caiete critice 1-2/1983: 148-149.

Buzura, Augustin. Fețele tăcerii (The Faces of Silence). Cartea Românească, 1974. 
Cordoș, Sanda. Lumi din cuvinte (Worlds from Words). Cartea Românească, 2012.

Corniș-Pop, Marcel. "Romanul politic - forme și etape" ("Political Novel - Forms and Stages"). Orizont 45/1979: 3.

Cosma, Anton. Romanul românesc contemporan. Proza (The Romanian Contemporary Novel. The Realism). Eminescu, 1988.

Dauriac, Emmanuelle. “«Romanul politic» și critica sub Ceaușescu...” (“The «Political Novel» and Criticism under Ceaușescu...”), translated by Marcela Sîrbu and Cornelia Alexandru. Vatra 3-4/2004: 48-55.

Gârdan, Daiana. "Evoluția romanului erotic românesc din prima jumătate a secolului al XX-lea. Între exercițiu și canonizare" ("The Evolution of the Romanian Erotic Novel from The First Half of the $20^{\text {th }}$ Century. Between Exercise and Canonization”). Transilvania 7/2018: 5-10, 2018a.

Gârdan, Daiana. "The Great Female Unread. Romanian Women Novelists in the First Half of the Twentieth Century: a Quantitative Approach.” Metacritic Journal for Comparative Studies and Theory 4.1/2018: 109-124, $2018 \mathrm{~b}$.

Goldiș, Alex. "Pentru o morfologie a romanului «obsedantului deceniu»" ("For a morphology of the «obsessive decade» novel”). Caietele Sextil Puşcariu. III. Cluj-Napoca, 2017: 494-502.

---. "Literary Interferences in Subversive East-European Prose under Communism." The Culture of Translation in Romania/ Übersetzungkultur und Literaturübersetzen in Rumänien, edited by Maria Sass, Ștefan Baghiu and Vlad Pojoga. Peter Lang, 2018: 85-97.

Holban, Ioan. "Viața ca text și textul ca viață" ("Life as text and text as life"). România literară 43/1981: 4.

Iovănel, Mihai. Ideologïle literaturii în postcomunismul românesc (The Ideologies of Literature in Romanian Post-communism). Editura Muzeul Literaturii Române, 2017.

Jockers, Matthew L. Macroanalysis. Digital Methods and Literary History. University of Illinois Press, 2013.

Lossef, Lev. On the Beneficence of Censorship. Aesopian Language in Modern Russian Literature. Verlag Otto Sagner in Komission, 1984.

Malița, Liviu. Literatura eretică. Texte cenzurate politic între 1949 și 1977 (The Heretical Literature. Politically Censured Texts between 1949 and 1977). Cartea Românească, 2016. 
Manolescu, Nicolae. "Fețele adevărului” (“The Faces of Truth”). România literară 28/1974: 9 .

Manolescu, Nicolae. Arca lui Noe (Noah’s Ark). Volume II. Minerva, 1981.

Martin, Mircea. "Despre estetismul socialist" (“About Socialist Aestheticism”). România literară 45/2004: 19, 21.

Moretti, Franco. "Conjunctures on World Literature." New Left Review 1/2000, 2000 .

Moretti, Franco. "The Slaughterhouse of Literature.” Modern Language Quarterly 2000: 207-227, 2000b.

Moretti, Franco. Graphs, Maps, Trees. Abstract Models for a Literary History. Verso, 2005.

Negrici, Eugen. Literatura română sub comunism. Proza (Romanian Literature under Communism. Prose). Editura Fundației Pro, 2002.

Nistor, Viorel. Pactul ficțional și istoria: repere ale romanului politic românesc postbelic/ The Fictional Pact and History: Highlights of Romanian Political Post-war Novel. Editura Casa Cărții de Știință, 2012.

Preda, Marin. Marele singuratic (The Great Loner). Cartea Românească, 1972.

Simion, Eugen. "Un procedeu epic în «Marele singuratic»" ("An Epical Method in «The Great Loner»"). România literară 51/1973: 4.

Simion, Eugen. "Romanul românesc azi" ("The Romanian Novel of the Present Day"). Caiete critice 1-2/1983: 68-70.

Simuț, Ion. Literaturile române postbelice (Romanian Post-War Literatures). Şcoala Ardeleană, 2017.

Suleiman, Susan Rubin. Le roman à thèse ou l'autorité fictive (The Thesist Novel or The Fictional Authority). Presses Universitaires de France, 1983.

Țoiu, Constantin. Galeria cu viță sălbatică (Gallery with Wild Vines). Eminescu, 1976.

Tuite, Clara. "Not Guilty: Negative Capability and the Trials of Willian Hone." Censorship and the Limits of the Literary. A Global View, edited by Nicole Moore. Bloomsbury, 2015: 33-48. 